\title{
Evaluating Interventions Uptake in Indigenous Chicken Production in a Participatory Research with Smallholder Farmers in Kenya
}

\author{
Joseph M Ndegwa (Corresponding author) \\ International and Rural Development Department (IRDD) and School of Applied Statistics \\ The University of Reading, PO Box 237 Reading, RG6 6AR, Reading, UK \\ E-mail: j.n.ndegwa@ reading.ac.uk
}

Mead, R, Norrish, P, Shepherd, D. D.

International and Rural Development Department (IRDD) and School of Applied Statistics

The University of Reading, PO Box 237 Reading, RG6 6AR, Reading, UK

Kimani, C. W, Wachira, A. M.

Kenya Agricultural Research Institute, National Animal Husbandry Research Centre

PO Box 25, Naivasha, Kenya

Siamba, D. N.

Masinde Muliro University of Science and Technology,

Department of Biological Sciences

Received: April 1, $2014 \quad$ Accepted: April 18, 2014

doi:10.5296/jas.v3i2.5398ＵRL: http://dx.doi.org/10.5296/jas.v3i2.5398

\begin{abstract}
Indigenous chicken production system has long been characterised by low productivity due to among other factors, poor management, inadequate and poor feeding regime, poor (or lack)
\end{abstract}


of disease control measures, poor hygiene, inappropriate housing, negative attitudes, lack of technical knowledge and lack of institutional support in terms of policy and infrastructure. This research was carried out to evaluate uptake by farmers of improved management practices (interventions) and their effect on performance of indigenous chickens at farm level and consequences for farmer participation in the implementation of research activities. The research involved 200 farmers in five regions in three counties. Four villages were selected per region and10 farms in each village. Interventions housing, feed supplementation, vaccination and deworming were implemented by farmers and monitoring and evaluation carried out. Farmers used own local inputs in implementing the project interventions and recorded various project activities and outputs. The project was monitored over a span of five, 3 -months long periods. $25 \%$ of farmers in the entire five regions did not have housing as a treatment in any of 5 periods. Feed supplementation had high level of use by all farmers in each period. More farmers applied deworming in later periods, $25 \%$ had vaccination in period 1 , and $40 \%$ in period 5 . Periods $3-5$ generally seem to be the time most applications were done. Flock sizes rose from $10-20$ birds per farm to $20-30$. Farmer participatory research is a tool for technology testing and transfer and a quick and effective means of generating and disseminating information.

Keywords: Africa, Kenya; Indigenous chicken, Production, Interventions uptake, Participatory research

\section{Introduction}

In sub-Saharan Africa, about $80 \%$ of the population live in rural areas eking out a living from subsistence farming, often under very difficult climatic and economic conditions (Ndegwa et al., 2001a; Ndegwa, 2013), to meet household food requirements.

Indigenous chickens are among the many local resources available in rural areas which, if well managed, could ease the burden of the people. Over $90 \%$ of rural households keep and rear indigenous chicken in small flocks of about 20 birds (Ndegwa et. al., 1999; Mbugua, 1990; MOLD, 1990; Stotz, 1983). According to Ndegwa, (2013), indigenous chickens play a very significant role in rural livelihoods. In Kenya, and indeed in sub-Saharan Africa, indigenous chickens comprise over $70 \%$ of total poultry populations (MOLD, 1991). They produce about $50 \%$ of the total eggs and over $80 \%$ of the poultry meat produced in many countries in sub-Saharan Africa (Ndegwa et al., 1998a). Hence, there exists a potential for a local resource like indigenous chickens to turn around the misery that is the lives in rural areas as stated by Ndegwa, (2006) who also calls for an infrastructural and institutional support in research and development activities aimed at improving productivity at farm level.

Indigenous chicken system has generally been characterised by low productivity due to among other factors, poor management, inadequate and poor feeding regime, poor (or lack) of disease control measures, poor hygiene, inappropriate housing, negative attitudes, lack of technical knowledge and lack of institutional support in terms of policy and infrastructure (Ndegwa and Kimani, 1997). Hence the importance of creating awareness and education as emphasised by Thieme et al (2014). 
Proper harnessing of local resources of the poor people and their involvement in the research process can help bring about development of sustainable livelihoods and contribute to the fight on poverty alleviation in rural areas where the majority of the poor live (Ndegwa, 2013; Gonsalves et al., 2005 Ndegwa et al., 2001b; Okong'o et al 1998; Tuitoyet et al; 1999; Kitalyi, 1998; Dolberg, 2008; FAO, 2008, 2010 and SA PPLPP, 2011). Their number is mainly composed of women (Blair, 2000; Al-Sultan, 2001) who engage in subsistence agricultural activities as they struggle to survive and feed their families under often very hostile environments (Ndegwa et al., 2000, 1998b, 1999, 1997; Gueye, 2000). A number of authors (Fanworth, et al., 2013; SA PPLPP, (2011) and Dolberg, (2008) emphasise the fact that empowering women is key to poverty reduction as well as a key driver to agricultural productivity. According to FAO (2011), the agriculture sector is underperforming in many developing countries, and one of the key reasons is that women do not have equal access to the resources and opportunities they need to be more productive. FAO (2011) also recommends promoting gender equality and empowering women (Millennium Development Goal Schedule 3) in agriculture to win, sustainably, the fight against hunger and extreme poverty (MDG1).

Gonsalves, et al., (2005) write about new challenges to agricultural research and development that include shifting focus to less favourable environments, strengthening capacity of local farming communities to continuously learn and experiment ways of improving their agricultural livelihoods, research and development are no longer exclusive domain of scientist and that local stakeholders provide inputs to processes that find sustainable solutions. According to Okali et al., (1994) both farmers and researchers are involved at any or all points along a continuum of levels of participation.

There is however, little published peer-reviewed material regarding how benefits of participatory research are achieved in practice (Blackstock et al., 2007). This study and other related studies by same authors (Ndegwa et al., 2013, 2014) explores and explains importance of participatory research in practical terms.

This farmer participatory research was carried out between 1996 and 1999 to evaluate effects of improved management practices on performance of indigenous chickens at farm level and most importantly, the consequences for farmer participation in the implementation of the research activities. We were highly enthusiastic to work directly with farmers in their own surroundings, situations and circumstances in order to not only impart our ideas and visions, but also to learn from their rich experiences.

\section{Methodology}

The study involved selection of location ( 5 regions and 4 villages per region - Box 1 ), selection of farms based on farmer's willingness to participate (10 farms selected per village), training and sensitisation meetings (selected farmers and their neighbours plus frontline extension personnel), introduction of intervention options (see Box 2), implementation by farmers, and monitoring and evaluation. The farmers used their own local inputs in implementing the project interventions and recorded various project activities and outputs including some aspects of management and production. Sonaiya, E. B., (1998) also refers to 
use of local inputs in family poultry production. The project was monitored over a span of five, 3-months long periods. Monitoring was by a visit every three months to each farm to evaluate progress and confirm the farmer's records. This was also the time for more consultation and sharing of experiences.

There was however, a six-month gap between visits 2 and 3 when there was no visit to the farms due to the security concerns at the time especially in regions 1 and 2 . These factors might have therefore played a key role in the behavioural patterns of flock demography. For the purpose of this study, 'periods 1 - 5' refer to the records at the end of the period.

The study deals with initial analyses of the data recorded by the farmers. The aim was to investigate effects of the introduction of a number of interventions (improved management practices), referred in this context as treatments to each of the 200 farms selected across 20 villages in five different regions on the characteristic behaviour of these farms and their indigenous chicken flocks. The interventions were introduced through training and sensitisations services and consultations. Ten farms were initially selected in each village but some dropped out due to factors outside the scope of the study such as security concern

\section{Box 1 Regions and villages}

1. Laikipia Ngarua - low potential semi-arid, poor infrastructure and frequent livestock theft incidences. Selected villages (with average farm sizes) were, 1 - Kinamba (2 acres); 2 - Sipili (2.5 acres); 3 - Cheleta (10 acres); 4 - Ol Moran (1 acre).

2. Ol Kalou - low to high potential and cold with frequent frost and water logging incidences. Has impassable road network for transportation during wet seasons. The selected villages were: 1) Ol Kalou South with average farm size of 2.5 acres; 2) Passenga with 5 acres as the average farm size; 3) Mirangine with average farm size of 2 acres and 4) Kaibaga with average farm size of 1 acre.

3. Bahati - high potential with adequate rainfall and good soils for agricultural activities, with land size ranging from 5 to 0.25 acres per household and relatively good road network and market opportunities. The selected villages (with average farm sizes) were, 1) Kabazi (1.5 acres); 2) Munanda (2 acres holdings); 3) Scheme (3 acres); 4) Wanyororo (0.5 acres).

4. Njoro -high to medium potential with good to poor road network and market opportunities. The selected villages (with average farm sizes) were, 1) Piave ( 2.5 acres); 2 ) Gichobo (5 acres); 3) - Njokerio (0.25 acres); 4) Likia (1.5 acres).

5. Naivasha - low potential, porous volcanic soils of high infiltration. Good to poor road network especially during wet periods villages (with average farm sizes) were: 1) Karate (1.5 acres); 2) Maraigushu (2.5 acres); 3) Karai (5 acres); 4) Mirera (1 acres).

\section{Results and Discussion}

The records on all the treatments (interventions) uptake were analysed for 173 farms disaggregated by region and village and is shown in Table 1. Half of the villages had their original total of 10 selected farms with records on flock demography and treatment 
characteristics. The average number of farms with records in each village was 8.7. The shortfall in the number of farms with records on treatments uptake is mostly indicative of drop out by some from the project. This scenario points to the complexity of participatory on-farm experimentation and the need for input of statistical expertise in designing stage.

\section{Box 2. Indigenous chicken project improved intervention options and how they were adapted by farmers}

1. Housing: (Reference: Ndegwa, et al 1998b)

- majority of farmers had adopted housing interventions designed to provide shelter from heat, wind cold, rain, thieves, and predators; provide adequate ventilation, lighting and space for birds, feeders, drinkers, nests, resting rafts and for people getting in and out with ease, easy to clean and disinfect to prevent diseases, internal and external parasite infestation. Features included:

- Roofing(farmers used materials such as iron sheet, plastic sheeting, reeds ('makuti') and grass)

- Walls (had to be smooth - mainly mud, some timber, others rafters)

- Floor (dry and smooth and had to be kept clean - mostly earthen, some raised timber, a few were cemented)

- Chicken run (provided scavenging area to glean feeds and exercise - farmers used chicken wire, chain link, offcut timber or droppers)

- Chick pen (high priority for chicks rearing up to 8 weeks, and which contributed to relatively very low mortality levels of $5-20 \%$ compared to over $80 \%$ normally reported for ordinary systems(Ndegwa et. al., 1999) - most were portable made from timber, tin, wire mesh, intertwined rafters, and reeds baskets)

2. Feeding: (Reference: Ndegwa J. M., 1992a, 1992b; Ndegwa, et al 1998b)

- recommendation on feeding was for a free-choice system comprising both scavenging and supplementation

- almost all farmers supplemented their chicken flocks using mostly local materials (cereal grains - maize, sorghum, millet, wheat, oats, barley; boiled potatoes tubers and peelings, sweet potatoes (Ipomeo batata), cassava (Tapioca), arrow roots, beetroots, carrots; pumpkins, boiled grain and leafy amaranthus ('terere'), sesame seeds (Sesamum indicum), green vegetables, leafy weeds, grasses; fullfat oiseeds - sunflower, rapeseed,'thawani' (rapeseed family), croton megalocapus ('mukinduri'), groundnuts; cooked legume seeds and leafy parts - peas, beans;leuceana, cariandra, and sesbania;in-season fruits - avocados, plums, mangoes, pineapple, bananas;mineral sources - ground egg shells, ash, common salt)

- a few farmers bought external materials to feed their birds (compounded feeds, fishmeal, maize bran, cotton seed meal, soya meal, sunflower meal, bone meal, limestone, common salt, mineral and vitamin premix) 
- scavenging was practised by all farmers mainly within 'runs' or enclosures during cropping and around the homestead and farm when there was no crop

- clean and relatively cool water was also provided by all farmers in a variety of containers

3. Health management: (Reference: Siamba, et al 1998; Ndegwa, et al 1998b)

- to prevent and treat diseases some farmers used either or both conventional and traditional strategies:-

- almost all farmers used traditional medication and some did not use any conventional methods.

- conventional medication included:

a) vaccination against Newcastle disease;

b) drugs for respiratory, gut and other problems;

c) control and treatment of endo-parasites - helminths using dewormers

d) control and treatment of ecto-parasites - mites, fleas and lice using powders

- traditional medication was done using a variety of materials e.g. Aloe spp.('mugwanugu', 'thukurui'), hot pepper, garlic, Mexican marigold ('mubangi'), stinging nettle ('thabai'), neem, pumpkin leaves, pyrethrum, black soot('carbon'), hot ashes;

- other strategies included maintaining clean chicken houses and use of disinfectants such as 'kerol' or magadi soda and spraying walls with acaricides.

4. Hatching and Brooding: (Reference: Ndegwa, et al 1998b)

- this was a strategy to produce replacement and incremental flocks rather than buying replacement day-old chicks from a commercial hatchery as is the case with commercial poultry systems.

- the strategy also focused on minimising flock mortality associated with unimproved systems.

Hatching (synchronised and consecutive) involved use of a cock:hen ration of 1:10 to maximise fertility, proper nests (dry, clean, good litter material, quiet, with less light, isolated).

- Synchronised hatching - several hens let to get broody and provided incubation eggs at the same time.

- Consecutive hatching - a broody hen provided with incubation eggs immediately chicks are hatched repeatedly for up to 5 times.

- These strategies ensured farmers got many chicks at once hence increasing flock size several fold within a short period of time. 
- Only a few farmers, though were able to apply synchronised and consecutive hatching

Brooding aimed at preventing chick mortalities by providing good management:

- separating chicks from mature birds - special chick housing (portable baskets, pens, isolated chick area).

- feeding good quality feed - high energy and protein, well ground

- clean cool drinking water

- protection against cold, predators, diseases,

5. Breeding: (Reference: (Ndegwa, et al 1998b)

-aimed at improving genetic potential of indigenous chickens

- maintaining of cock:hen ratio of 1:10,

- selecting high performers(eggs and growth) and good features (large body size, sturdy)

- avoiding inbreeding (removal of cocks after six months and exchanging with others farmers)

To sustain enthusiasm and revive interest among the farmers, we used some persuasion and education with a good measure of success. Most kept up-to-date records even when we took a longer time to visit them and even long after the project had been phased out. This happened also in areas where serious insecurity problems had previously occurred forcing many people to temporarily flee their homes.

Generally, the response on records keeping was encouraging. The treatments uptake had the most records and it seems many farmers found these easier to handle. All the variables were based on farmer records. The intervention treatment included the four explanatory variables housing, vaccination, de-worming and feed supplementation, introduced through a process of training and sensitisation of farmers. Exploratory variables to investigate effects were the flock demography and the production characteristics discussed in Ndegwa, (2013). 
Table 1. Number of farms in 20 villages with records on treatment uptake

\begin{tabular}{|l|l|l|}
\hline Region/Village & Number of selected farms & Treatment/Flock Demography \\
\hline $1 / 1$ & 10 & 10 \\
\hline $1 / 2$ & 10 & 10 \\
\hline $1 / 3$ & 10 & 10 \\
\hline $1 / 4$ & 10 & 7 \\
\hline $2 / 1$ & 10 & 10 \\
\hline $2 / 2$ & 10 & 8 \\
\hline $2 / 3$ & 10 & 8 \\
\hline $2 / 4$ & 10 & 7 \\
\hline $3 / 1$ & 10 & 9 \\
\hline $3 / 2$ & 10 & 10 \\
\hline $3 / 3$ & 10 & 9 \\
\hline $3 / 4$ & 10 & 6 \\
\hline $4 / 1$ & 10 & 10 \\
\hline $4 / 2$ & 10 & 7 \\
\hline $4 / 3$ & 10 & 9 \\
\hline $4 / 4$ & 10 & 3 \\
\hline $5 / 1$ & 10 & 10 \\
\hline $5 / 2$ & 10 & 10 \\
\hline $5 / 3$ & 10 & 10 \\
\hline $5 / 4$ & 10 & 10 \\
\hline & & \\
\hline
\end{tabular}

Application of the treatments depended on individual farms capacity, ability and time allocation. Farmers used their own local resources and new knowledge from the training to apply the treatments. Hence, the treatments were not uniform in all the farms.

Table 2 illustrates the treatment uptake raw data at period 1 for farms in each village and region, using an example farm from each village. Complete records from all the farms in the five regions and for the rest of the five periods are shown in appendix 5.2 in Ndegwa, (2006) but are generally in the form shown here.

The treatment uptake records illustrated here show whether and when a particular farmer implemented the specific treatment in the form of housing, vaccination, de-worming or feed supplementation. Once the housing treatment was applied, it inevitably remained applied in subsequent periods. In case of the other three treatments, application could have been done in one period and be skipped in the next period(s). When a treatment was applied in a certain period, this was indicated with a value of one, otherwise a zero was entered. For example, the first row shows that farm LK1 in village 1 and region 1, had applied housing and supplementation (each given a value of 1) in period 1, but did not apply vaccination and deworming (each given a value of 0 ) in the same period. 


\section{Macrothink}

Table 2. Treatment uptake from farms selected from 20 villages in five regions in period 1.

\begin{tabular}{|c|c|c|c|c|c|c|}
\hline \multirow{2}{*}{ Region } & \multirow{2}{*}{ Village } & \multirow{2}{*}{ Farm } & \multicolumn{2}{|c|}{ Treatment Uptake $^{1}$} \\
\cline { 4 - 7 } & & & Housing & Vaccination & Deworming & Supplementation \\
\hline 1 & $1(\mathrm{LK})$ & LK1 & 1 & 0 & 0 & 1 \\
\hline 1 & $2(\mathrm{LS})$ & LS1 & 0 & 0 & 0 & 1 \\
\hline 1 & $3(\mathrm{LC})$ & LC1 & 1 & 0 & 0 & 1 \\
\hline 1 & $4(\mathrm{LO})$ & LO3 & 1 & 0 & 0 & 1 \\
\hline 2 & $1(\mathrm{OS})$ & OS1 & 1 & 0 & 0 & 0 \\
\hline 2 & $2(\mathrm{OP})$ & OP1 & 0 & 0 & 1 & 1 \\
\hline 2 & $3(\mathrm{OM})$ & OM1 & 0 & 0 & 0 & 1 \\
\hline 2 & $4(\mathrm{OK})$ & OK2 & 1 & 0 & 0 & 1 \\
\hline 3 & $1(\mathrm{BK})$ & BK1 & 0 & 0 & 1 & 1 \\
\hline 3 & $2(\mathrm{BM})$ & BM1 & 1 & 0 & 1 & 1 \\
\hline 3 & $3(\mathrm{BS})$ & BS1 & 0 & 0 & 0 & 1 \\
\hline 3 & $4(\mathrm{BW})$ & BW1 & 1 & 1 & 1 & 1 \\
\hline 4 & $1(\mathrm{NP})$ & NP1 & 1 & 0 & 0 & 1 \\
\hline 4 & $2(\mathrm{NG})$ & NG1 & 1 & 1 & 1 & 1 \\
\hline 4 & $3(\mathrm{NN})$ & NN1 & 0 & 1 & 1 & 1 \\
\hline 4 & $4(\mathrm{NL})$ & NL1 & 0 & 0 & 0 & 1 \\
\hline 5 & $1(\mathrm{NSK})$ & NSK1 & 0 & 0 & 0 & 1 \\
\hline 5 & $2(\mathrm{NM})$ & NM1 & 1 & 0 & 0 & 1 \\
\hline 5 & $3(\mathrm{NKR})$ & NKR1 & 1 & 0 & 0 & 1 \\
\hline 5 & $4(\mathrm{NMR})$ & NMR1 & 1 & 0 & 1 & 1 \\
\hline
\end{tabular}

${ }^{1}$ Treatment Uptake: $0=$ treatment not applied; 1 = treatment applied

Looking at this illustration, the treatment uptake characteristics, housing and supplementation had most entries with one indicated. The records for the other four periods were similar to this illustration.

Levels of treatment uptake per farm are calculated as totals for each form of intervention. These are illustrated in Table 3 for the selected sample of farms in the 5 regions. 
Table 3. Levels of treatment uptake distribution for 20 farms selected from 20 villages in five regions as totals for 5 periods

\begin{tabular}{|l|l|l|l|l|l|l|}
\hline \multirow{2}{*}{ Region } & \multirow{2}{*}{ Village } & \multirow{2}{*}{ Farm } & \multicolumn{4}{|l|}{ Treatment $^{1}$} \\
\cline { 4 - 8 } 1 & & & totHse & totVac & totDwm & totSpl \\
\hline 1 & 2 & LS1 & 2 & 0 & 2 & 4 \\
\hline 1 & 3 & LC1 & 5 & 0 & 1 & 5 \\
\hline 1 & 4 & LO3 & 5 & 1 & 1 & 5 \\
\hline 2 & 1 & OS1 & 5 & 1 & 1 & 4 \\
\hline 2 & 2 & OP1 & 4 & 3 & 5 & 5 \\
\hline 2 & 3 & OM1 & 4 & 1 & 3 & 5 \\
\hline 2 & 4 & OK2 & 5 & 1 & 3 & 5 \\
\hline 3 & 1 & BK1 & 4 & 2 & 3 & 5 \\
\hline 3 & 2 & BM1 & 5 & 2 & 5 & 5 \\
\hline 3 & 3 & BS1 & 3 & 0 & 4 & 5 \\
\hline 3 & 4 & BW1 & 5 & 4 & 4 & 5 \\
\hline 4 & 1 & NP1 & 5 & 3 & 3 & 4 \\
\hline 4 & 2 & NG1 & 5 & 2 & 3 & 5 \\
\hline 4 & 3 & NN1 & 4 & 2 & 3 & 5 \\
\hline 4 & 4 & NL1 & 3 & 1 & 3 & 4 \\
\hline 5 & 1 & NSK1 & 0 & 3 & 1 & 5 \\
\hline 5 & 2 & NM1 & 5 & 1 & 2 & 5 \\
\hline 5 & 3 & NKR1 & 5 & 1 & 2 & 5 \\
\hline 5 & 4 & NMR1 & 5 & 1 & 2 & 5 \\
\hline
\end{tabular}

${ }^{1}$ Treatment:

totHse $=$ total periods housing intervention was applied

tot $\mathrm{Vac}=$ total periods vaccination intervention was applied

totDwm $=$ total periods deworming intervention was applied

totSpl $=$ total periods supplementation intervention was applied

The levels ranged from $0-5$, indicating the number of times a given treatment was applied out of the possible 5 periods $(0$ - not applied at all in 5 periods; 5 - applied in all the 5 periods). For example, Total Housing uptake for 5 weeks (totHse) was obtained from: 
Housing1 + Housing $2+$ Housing $3+$ Housing $4+$ Housing 5

i.e. sum of housing values in periods $1-5$.

In our illustration, farm LK1 in village 1 of region 1 had a totHse with a value of 5 meaning that housing was done at each of the five periods. The same farm had a total Vaccination uptake (totVac) of value zero, a total Deworming uptake value of 1 and a total supplementation value of 4

Two forms of diagrams are used to describe the pattern of uptake of interventions. The first is the frequency distribution of levels of each treatment shown by Fig 1 corresponding to the treatments housing, vaccination, deworming and supplementation respectively, as a pattern for each region. These levels indicate the number of times or periods a treatment was applied and range from 0 (no application at any period) to 5 (application of an intervention in each period).

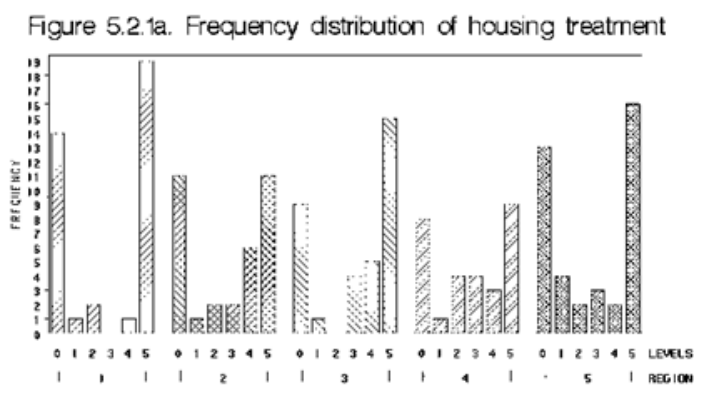

Figure 5.2.1c. Frequency distribution of deworming treatment

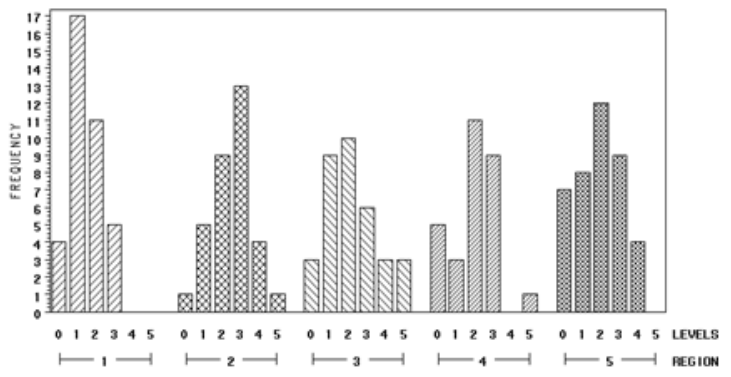

Figure 5.2.1b. Frequency distribution of vacaination treatment

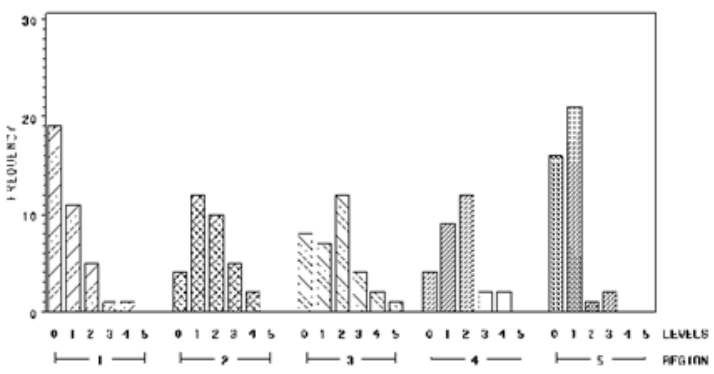

Figure 5.2.1d. Frequency distribution of feed supplementation treatment

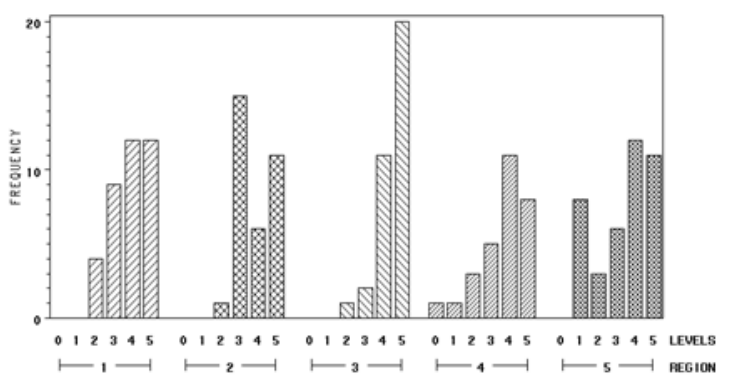

Figure 1. Frequency distribution of levels of treatments

The housing frequencies of farmers at levels of 0 and 5 in each region were larger compared to the frequencies at other levels. This is because of the fact that many of those who applied housing intervention as defined for the experiment, did so in period 1 and being a physical, more durable and non-consumable structure, it would be reflected in other periods. Only a few farmers had housing at levels 1 to 4 showing a few taking up housing after the initial period. One farmer in each of the regions $1-4$ and 3 farmers in region 5 applied housing only once, which must mean the use of housing for the first time at period five. The proportion of farmers not using housing at all was large and as discernible as that of the farmers using housing all the time in each region. Regions 1 and 5 had the largest proportions in this category.

Having housing in all the five periods, implies that one had also housing treatment in period 1. 
From Figure 1, 30\% of all the farmers in the five regions had housing in period 1. Generally, only a quarter of farmers in the entire five regions did not have housing as a treatment in any period. This is a good reflection of the enthusiasm farmers had in taking up our interventions right from the beginning.

Housing intervention as a scientific technology was a familiar entity to the farmers although many of them had not felt the need to invest in it before. They easily understood from our training sessions its importance in reducing losses from vagaries of weather, theft, predation and infection by diseases. The application of housing was also easily affordable using locally available materials. Hence, the high frequencies at level 5 observed in all the five regions indicate early and sustained use by a large proportion of farmers. The reasons why some farmers did not use housing at all may be a reflection of their high level of poverty and hence they could not afford to invest in this activity. A majority of those who were able applied housing early in the project period.

The vaccination frequency distribution pattern is shown in Figure 1. The most frequent levels are 0,1 and 2 in all regions except for region 5. There was hardly any vaccination at level 5 . The zero level had a high frequency in regions 1 and 5. In general, most of the farms that had vaccinated had only done it once or twice. Regions 1 and 5 had the largest proportions of farmers (38 and 50\% respectively) who did not vaccinate at any period. However, only about one quarter of farmers in all the five regions did not vaccinate at any period. This again is another good indication of the enthusiasm for participation in the project's activities by the farmers. Most vaccination was done on a group basis whereby farmers in a group jointly bought vaccine and shared doses. It is unlikely that individual farmers could have afforded to act independently due to the high cost and dosage packing of the vaccine.

The deworming pattern of levels of application shows a distribution with a peak in the middle with more farmers at levels 2 and 3 than at other levels in all the regions. There were only 3 farms ( 1 in region 2 and 2 in region 3) at level 5 overall. Hence, regular use of deworming was not frequently practised but the majority of the farms had dewormed at some period. Only a minority (10\%) of the farmers in the entire five regions had not had deworming at any period at all. Deworming was done using anti-helminthic drugs easily available and cheap from local drug shops. Lack of application in every period was mainly because farmers were not able to discern or understand its importance in management of their flocks. However, this usage was a good indication of farmers' willingness to try out new formal ideas they learned from our training sessions.

The feed supplementation frequency distribution on levels of application was skewed to the right with most of the farmers at level 3 and above in every region as shown by Figure 1. There was generally an upward trend in the number of farmers from period 1 to 5 . Almost all farmers had supplementation at least in one period. Close to a quarter of the farmers in each region applied supplementation in all five periods. Region 3 had the highest number of farmers at level 5 with more than half of them applying supplementation in every period. Application at levels 1 and 2 was by only a small number of farmers (only one farmer at level 2 while the other regions had between 4 and 5 farmers). 
The second diagram describing the pattern of intervention uptake is shown by Fig 2 and provides a chronological summary of the numbers of farmers taking up the interventions on housing, vaccination, de-worming and feed supplementation in periods 1 to 5 and in each of the regions 1 to 5 .

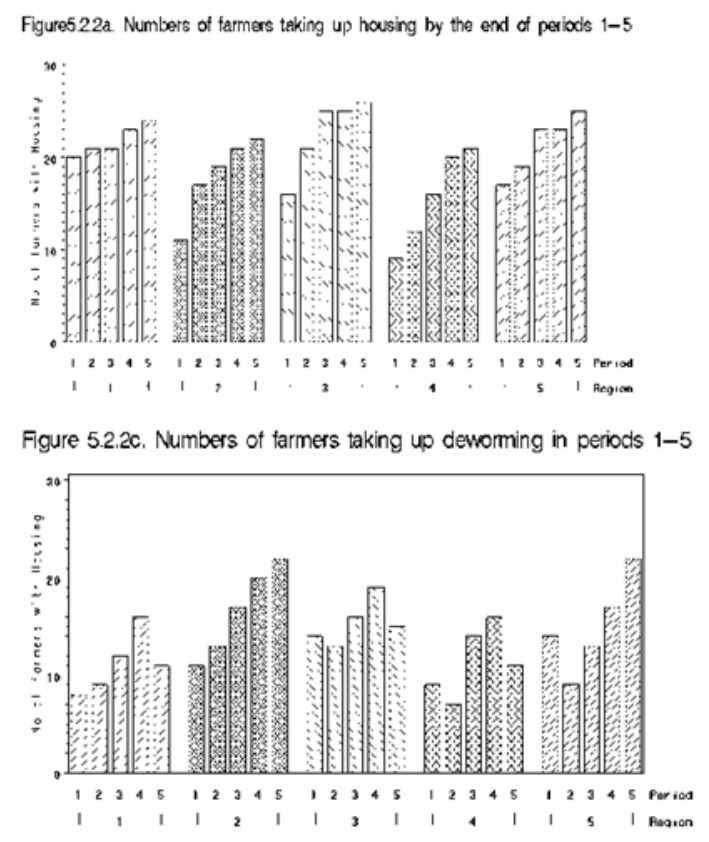

Figure 5.2.2c. Numbers of farmers taking up deworming in periods $1-5$

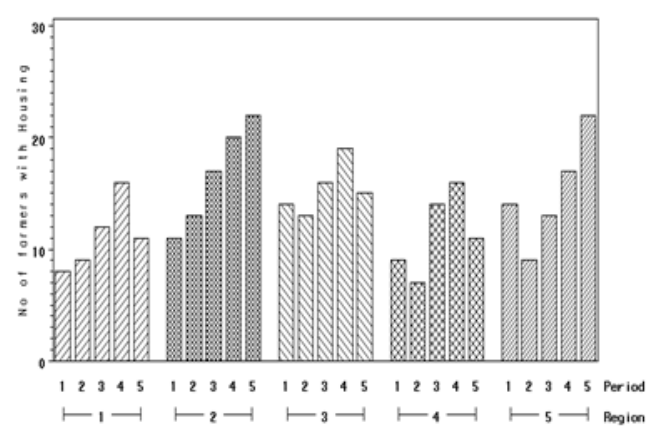

Figure 5.2.2b. Numbers of famers taking up vaccination in periods $1-5$

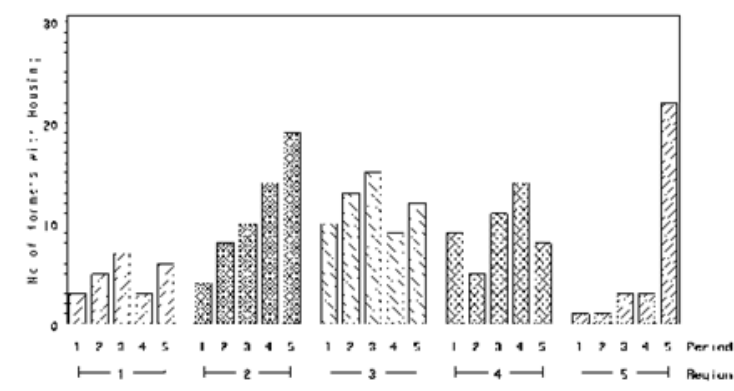

Figure $5.22 \mathrm{~d}$. Numbers of farmers taking up feed supplementation in periods $1-5$

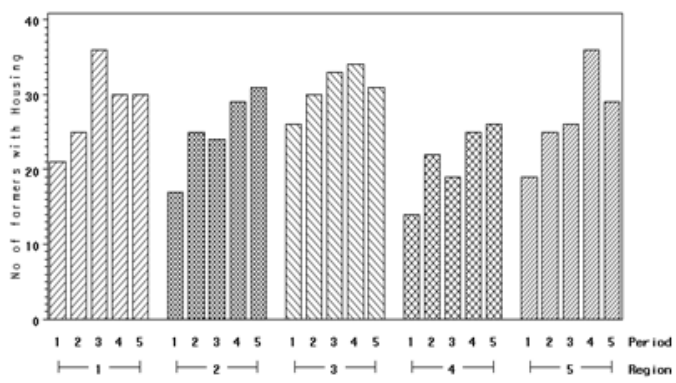

Figure 5.2.2d. Numbers of farmers taking up feed supplementation in periods $1-5$

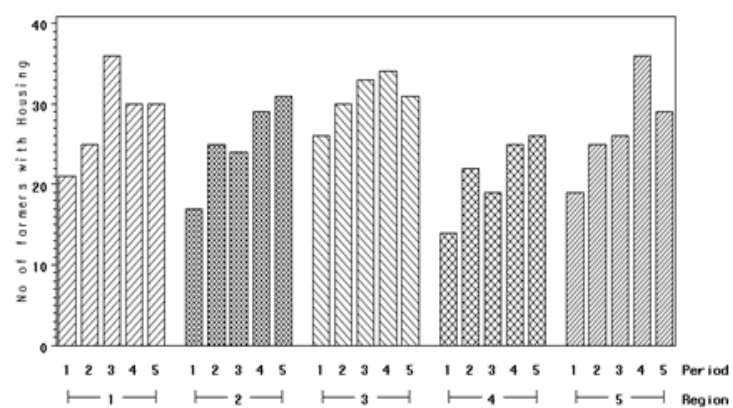

Figure 2. Pattern of interventions uptake in 5 periods in 5 regions

The housing pattern for the number of farmers, who applied in each period, shows an upward trend in all the 5 regions (Fig 2). Region 1 had more farmers with housing in periods 1 and 2 than the other regions with only regions 3 and 5 surpassing it in latter periods. Region 3 was similar to region 5 while region 2 was similar to region 4 in the number of farmers with housing. About $58 \%$ of farmers in the entire five regions had housing in 5 periods. The first diagram in Figure 1 showed that $30 \%$ of farmers had housing in period 1 hence the upward trend. Generally, the housing treatment was applied widely and frequently in all regions.

The time distribution pattern of the number of farmers using vaccination shows a general increase with period in all the regions. Regions 2, 3 and 4 had generally highest number of farmers doing the vaccinations. Generally, most application was in done in later periods 3, 4 and 5. 


\section{Mll Macrothink}

Period 5 in regions 2 and 5 recorded the largest number of applications with about $50 \%$ of farmers doing vaccination in period five. Close to $30 \%$ of the farmers did vaccination in period five in all five regions. Region 3 had almost the same number of applications in every period. However, the pattern of the vaccination uptake in region 5 was completely different from those in the other four regions with only a few farms having done vaccination in periods 1-4 while period 5 had a large number of farms vaccinating. This was probably due to a late realisation of its importance by the farmers but there was also an element of organised group vaccination at this period.

The pattern of the numbers of farmers taking up deworming treatment in Fig 2 shows that more farmers applied deworming in later periods giving an upward trend of the number of farmers deworming over the periods. About 25 percent of farmers had vaccination in period 1 , and about $40 \%$ in period 5. Periods $3-5$ generally seem to be the time most applications were done. Regions 1 and 4 had similar patterns and both had the least application rates generally.

The pattern for the number of farmers taking up feed supplementation at each period and in each region provided by Fig 2 shows there was a small upward trend in the number of farmers who supplemented their chicken flocks from period 1 to 5 in each region with period 1 registering at least 10 farmers. Region 4 had the least number of farmers in each period compared to the other regions. Close to $50 \%$ of farmers generally, had supplementation at each period.

The two sets of diagrams provide an understanding of the treatment application in terms of number of times it was done, period of application and number of farmers involved. They also provide information on important regional differences if any, on application of the treatments.

The feed supplementation and the housing interventions seemed to have been applied early in the study and in the rest of the later periods by majority of the farmers, although they have rather different patterns because housing has non-decreasing levels. There is little variation between periods in the take up of the two interventions. Similarly, there were little regional differences in these interventions though region 4 was low on both. These two treatments were applied by use of locally available resources and hence many farmers found it possible to take them up from the early periods across the regions.

Summaries of the total numbers of treatment applications and the average levels of treatment application in 5 regions, over the entire 5 periods are provided in Table 4 and Table 5 respectively. These summaries support the arguments presented about the treatment levels and number of farmers. 
Table 4. Total numbers of treatment applications in regions $1-5$.

\begin{tabular}{|c|c|c|c|c|}
\hline \multirow{2}{*}{ Region } & \multicolumn{4}{|c|}{ Treatment } \\
\cline { 2 - 5 } & Housing & Vaccination & Deworming & Feed Supplementation \\
\hline 1 & 109 & 24 & 56 & 142 \\
\hline 2 & 90 & 55 & 83 & 126 \\
\hline 3 & 113 & 59 & 77 & 154 \\
\hline 4 & 78 & 47 & 57 & 106 \\
\hline 5 & 107 & 30 & 75 & 135 \\
\hline Total & 497 & 215 & 348 & 663 \\
\hline Proportion & $50 \%$ & $21 \%$ & $35 \%$ & $66 \%$ \\
\hline
\end{tabular}

Table 5. Average total level of treatment application in 5 periods in regions $1-5$.

\begin{tabular}{|c|c|c|c|c|c|}
\hline \multirow[t]{2}{*}{ Region } & \multirow[t]{2}{*}{ Number of farms } & \multicolumn{4}{|c|}{ Treatments $^{1}$ mean total values } \\
\hline & & Thse & Tvac & Tdwm & Tspl \\
\hline 1 & 37 & 2.8 & 0.7 & 1.4 & 3.9 \\
\hline 2 & 33 & 2.7 & 1.7 & 2.5 & 3.8 \\
\hline 3 & 33 & 3.1 & 1.6 & 2.1 & 4.4 \\
\hline 4 & 26 & 2.6 & 1.6 & 2.0 & 3.7 \\
\hline 5 & 40 & 2.6 & 0.7 & 1.9 & 3.4 \\
\hline \multicolumn{2}{|c|}{ standard deviation range } & $2.0-2.4$ & $0.8-1.3$ & $0.9-1.3$ & $0.7-1.5$ \\
\hline
\end{tabular}

Treatments $^{1}$ :Thse $=$ Total level of housing; Tvac $=$ Total level of vaccination; Tdwm $=$ Total level of deworming; Tspl = Total level of feed supplementation. Maximum level is 5 .

So the understanding by farmers about some basic nutritional science and the fact that most of the required nutrients could be found among local materials, might have greatly influenced the observed response by farmers in the application of feed supplementation treatment.

In general terms, feed supplementation had not only a high level of use by all farmers in each period, but also a high number of farmers taking it up early in the study. This observation is an indication of positive farmer response to our prior training and sensitisation sessions, where emphasis was put on the importance of feed supplementation to meet birds' nutritional requirements using locally available feed resources. This was a feasible innovation for anyone who recognised inherent livelihood opportunities in the research process. Strict emphasis was particularly placed on the need to feed young chicks with high protein rich feedstuffs. So the understanding by farmers about some basic nutritional science and the fact that most of the required nutrients could be found among local materials, might have greatly influenced the observed response by farmers in the application of feed supplementation treatment.

The vaccination and deworming treatments tended to have more variation between periods and regions. The majority of farmers in regions 3 and 5 applied the two treatments in period 5 . 
The pattern in region 5 is very different from the other 4 regions for the vaccination, which differed mainly on the number of farmers. Vaccination in particular needed greater technical and monetary intervention than other treatments and was applied by farmers in different villages and regions at different periods of time.

Application of deworming had a resonance with that for vaccination in that both were generally done up to a total of 3 times, and in the later periods. This was due to the fact that this was 'new science' for most of the farmers and application of both treatments required investment in external inputs, which most farmers had difficulty affording early in the project. Most farmers seemed to have taken time also to understand and probably appreciate the importance of applying vaccination and deworming. With time, and because of persuasion from the research team, some farmers were able to take them up in later periods of the process. The deworming was particularly baffling to a majority of the farmers who had no prior knowledge of likelihood for infestation of their chicken flocks by internal worms and the implications for the flock's performance.

\section{Conclusions}

One of the objectives of the study was to have the farmers participate fully and actively in the research process as a novel approach to technology transfer. Such farmers would benefit directly from the research by appreciating its significance. They would also understand better what a technology entails and be able to apply the same within their personal circumstances and situations. There was also the hope that other non-participating farmers would be influenced by and learn from the farmers who were involved in the research. Looking at the patterns of distribution of levels of treatments uptake and the numbers of farmers applying a technology over the periods, a great deal has been done towards the achievement of the stated objectives. Farmer's enthusiasm in the research process was created and was a major driving force that helped to sustain the impetus.

Farmer participatory research can therefore be seen, from the perspective of the current study, to be a tool for technology testing and transfer at the very point it is needed and designed to support. This is a quick and effective means of generating and disseminating information. The weakness of the tool however, is that it is dependent on development of enthusiasm among its clientele and is difficult to control and minimise random variation for ease of statistical analysis and investigations. A hundred and seventy three farms out of the 200 originally selected had records on treatments and this to me is exciting as it is an indication of strong farmer participation in the research process through implementation activity. There were a similar number of farms across the regions (except in region 4 , which had only half the original number of farms selected) which suggests little regional variation in support for these processes.

The use of available local resources enhanced early uptake of housing and supplementation by farmers. This point to the potential need for the provision of credit inputs to enable farmers to secure other resources required to implement project activities, particularly early on. Creation of enthusiasm and interest among target groups require strengthening their capacity to be able to undertake and implement project activities. 


\section{Acknowledgement}

I would like to extend my gratitude first to my supervisor, Professor Roger Mead at the school of Applied Statistics, University of Reading UK. Much appreciation is also extended to my other supervisors at the department of International and Rural Development (IRDD), Dr Patricia Norrish and Derek Shepherd, my great mentors at the University of Reading. Many thanks also to other people at both the Applied Statistics and IRDD for their great support and encouragement. I would also wish to thank the Director, Kenya Agricultural Research Institute and the Centre Director, KARI, Naivasha, and the staff at both the headquarter and Naivasha, for their support and great understanding. Special mention is deserved for my colleagues at Naivasha with whom we executed this farmer participatory study. Special thanks to my former colleagues, Catherine Kimani and Dr Donald Siamba for their contribution. Many other colleagues at KARI and all the extension friends in all the locations we visited are greatly acknowledged for their contributions and enthusiasm led by Gathu Munga. I'm grateful to Mr J. Kiptarus and Mrs C. Ngunjiri at the Ministry of Livestock Development Headquarters Nairobi for their cooperation and partnership in many poultry activities across our country Kenya.

\section{References}

Dolberg, F., (2008). Poultry production for livelihood improvement and poverty alleviation. O. Thieme and D Pillings, eds. Poultry in the 21st century: Avian influenza and beyond. Proceedings of International Poultry Conference held 5-7 November, Bangkok, FAO Animal Production and Health Proceedings, No. 9.

Fanworth, C., Sudell, M., Nzioki, A., Shivutse, V., \& Dan, M. (2013). (eds).Transforming gender relations in agriculture in Sub-Saharan Africa. Swedish International Agricultural Network Initiative (SIAN), Stockhom Environmental Institute, Sweden.

FAO, (2008). Poultry in he 21st century: Avian influenza and beyond. O. Thieme and D Pillings eds. Proceedings of International Poultry Conference held 5 - 7 November, Bangkok, FAO Animal Production and Health Proceedings, No. 9. Rome FAO. (Available at ftp://ftp.fao.org/docrep/fao/011/i0323e/i0323e.pdf).

FAO, (2010). Smallholderpoultyr production: Livelihoods, food security and socio-cultulral significance. K. N. Kryger, K. A. Thonsen, M. A. Whyte and M. Dissing. (available at www.fao.org/docrep/013/al.674e/al674e00.pdf)

FAO, (2011). Women in Agriculture: Closing the gender gap for development. The state of food and agriculture, 2010-2011. FAO of UN, Rome, Italy. [Online] Available: http://www.fao.org/publication/sofa/2010-11/en.

Gonsalves, J., Becker, T., Braun, A., Camplan, D., Chavev, H., Fajber, E., Kapiriri, M., Rivacamirade, J., Vernooy, M. (edts) (2005). Participatory research and development for sustainable agriculture and natural resource management: A sourcebook Vol 1: Understanding research and development. International Potato Centre - Users' Perspectives with Agricultural Research and Development, Laguna, Philippines and International Development Research 
Centre, Ottawa, Canada.

Gueye, E. F. (2000). The role of family poultry in poverty alleviation, food security and the promotion of gender equality in rural Africa. Outlook on Agriculture. 29(2), 129-136. http://dx.doi.org/10.5367/000000000101293130

Kitalyi, A. J. (1998). Village chicken production system in rural Africa: Household food security and gender issues. FAO Animal Production and Health Paper, 142. Rome, FAO. [Online] Available: ww.fao.org/docrep/003/w8989e/w8989e00.htm

Ndegwa, J. M., (1992a). Digestibility and Metabolic Energy determination of ground and unground sesame (Sesamum indicum) seeds in broiler diets. Msc Thesis, 1992, Wageningen Agricultural University, Wageningen, The Netherlands.

Ndegwa, J. M. (1992b). Use of sesame seeds (Sesamum indicum) in broiler feeds. Proceedings, IX World Poultry Congress - Young professionals program. October 1992. Amsterdam, The Netherlands.

Ndegwa, J. M., Mbugua, H. C. W.,Owango, M. O., \& Mburu, B. M. (eds) (1994). Proceedings of second Poultry Research Priority setting Workshop. Naivasha, 15-16 November. Kenya Agricultural Research Institute.

Ndegwa, J. M., \& Kimani, C. W., (1997). Rural poultry production in Kenya: Research and development strategies. In: Proceedings of 5th Kenya Agricultural Research Institute (KARI) scientific conference, October, 1996. KARI, Nairobi.

Ndegwa, J. M., Kimani, C. W., Siamba, D. N., Mburu, B. M., Mukisira, E. A., \& de Jong, R., (1999). Characteristics of rural poultry production in different agroecological zones in Kenya. In Proceedings of the 6th biennial Kenya Agricultural Research Institute (KARI) scientific conference 9-13 November 1998, pp 540 - 547. Nairobi, Kenya. KARI.

Ndegwa, J. M., Norrish, P. Mead, R., Kimani, C. W., Wachira, A. M., (2000). A research process and methodology focusing on indigenous Kenyan chickens. A paper presented at the Symposium of the International Network for Family Poultry Development (INFPD) at the XXI World's Poultry Congress. 20 - 24 August, 2000. Montreal, Canada. [Onl;ine] Available: http//www.fao.org//ag/againfo/subjects/en/infd/documents/newsletters/Infd111.pdf and http://www.fao.org/docrep/019/aq634e/aq634e.pdf - The Bangladesh model and other experiences in family poultry development. International Network for Family Poultry Development (INFPD) May-July 2002.

Ndegwa, J. M., Norrish, P. Mead, R., Kimani, C. W., Wachira, A. M. (2001a). The growth performance of indigenous Kenyan chicken fed diets containing different levels of protein during rearing. Tropical Ainamal Health and Production, 33(5), 441-448. http://dx.doi.org/10.1023/A:1010552008639

Ndegwa, J. M., D. D. Shephered1, Norrish, P.1 Mead, R., Kimani, C. W., Wachira, A. M., Siamba D. N., \& Githinji, M. M., (2001b). Participatory strategic approach to development of improved indigenous poultry systems in East Africa. A paper presented at the International 
Development Conference, Rotorua, New Zealand, 2-6 April (2001). [Online] Available: http://www.fao.org/docrep/019/aq634e/aq634e.pdf - 'The Bangladesh model and other experiences in family poultry development'. International Network for Family Poultry Development (INFPD) May-July 2002 and published in Global Journal of Agricultural Research Vol 1 No 2 pp $14 \quad-\quad 28$ also [Online] Available: (http://www.eajournals.org/journals/global-journal-of-agricultural-research-gjar/vol-1-issue-2 -september-2013/)

Ndegwa, J. M, Norrish, P. Mead, R., Kimani, C. W., Wachira, A. M., (2002). Hatching characteristics of eggs artificially incubated from six reciprocal crosses of indigenous Kenyan chickens. Tropical Agriculture (Trinidad), Vol. 9 No 1.

Ndegwa, J. M, Norrish, P. Mead, R., Kimani, C. W., Wachira, A. M. (2005). Growth characteristics of indigenous chickens lines and a cross with Rhode Island Red in Kenya. Tropical Agriculture (Trinidad)) Vol 82 No 1

Ndegwa, J. M., (2006). Participatory research approaches in development of improved management practices in indigenous chicken production system with smallholder farmers in Kenya. PhD. Thesis, University of Reading, UK.

Ndegwa, J. M, Norrish, P. Mead, R., D. D. Shephered, Kimani, C. W., Wachira, A. M., (2012). Growth characteristics of six reciprocal crosses of Kenyan indigenous chickens Journal of Agricultural Science Vol 4 No.6.Pp 160-170.

http://dx.doi.org/10.5539/jas.v4n6p160

Ndegwa, J. M. (2013) (ed). Improving indigenous chicken production in Kenya - A livelihood strategy. LAP Lambert Academic Publishing https:/www.lap-publishing.com/

Ndegwa, J. M, Norrish, P. Mead, R., D. D. Shephered, Kimani, C. W., Wachira, A. M., (2014). Investigating eggs hatchability in indigenous chicken system with smallholder farms in Kenya in a participatory research using analysis of variation. Journal of Applied Biosciences 80, 7000-7013. http://dx.doi.org/10.4314/jab.v80i1.6

Okali, C., Sumberg, J. and Farringto, J., (1994). Farmer participatory research. Rhetoric and reality. Intermediate Technology publications London, UK: Overseas Development Institute.

Okong'o, Kabuage, L., Mbugua, P. N. and Ndegwa, J. M., (1998). The effect of cooking grain amaranth (Amaranthus hypochodriacus) on its utilisation by broiler and indigenous chickens. In Proceedings of Rural Poultry Workshop. Kakamega, July 1998. Kenya

Pica-Ciamarra, V. and Dhawan, M. (2010). Small-scale poultry farming and poverty reduction in South Asia: From good good practices to good poilicies in Bangladesh, Bhutamn and India. New Delhi, South Asia pro-poor Livestock policy Programmes. [Online] Available: http//:sapplpp.org/lessonslearnt/smallscale-poultry-farming-and-poverty-reduction-in-south-a sia)

SA PPLPP, (2011). Proceedings of the Workshop in Bangladesh on "Implementation of the National Livestock Development Policy (2007) and National Livestock Development Policy 


\section{Macrothink}

Journal of Agricultural Studies

ISSN 2166-0379 2015, Vol. 3, No. 2

(2008): Impact on Small-scale Livestock Rearers". [Online] Available: http//:sapplpp.org/files/repository/information-hub/workshop\%20proceedings20\%28Babglad esh\%205thApril\%202011.pdf.

Thieme, O., Sonaiya, E. B., Alders, R., Saleque M. A., \& De Besi, C., (2014). Family poultyr development - Issues, Opportunities and Constraints. Animal Production and Health Working Paper No. 2. Rome (http//:www.fao.org/docrep/i019/i595e/i3595e.pdf).

Tuitoek, J. K., Chemjor, W., Ndegwa, J. M., \& Ottaro, J. M., (1999). Morphological characteristics and protein requirements of indigenous Kenyan chicken. In Proceedings of the 6th biennial Kenya Agricultural Research Institute (KARI) scientific conference

\section{Copyright Disclaimer}

Copyright for this article is retained by the author(s), with first publication rights granted to the journal.

This is an open-access article distributed under the terms and conditions of the Creative Commons Attribution license (http://creativecommons.org/licenses/by/3.0/). 